\title{
ESPIRITUALIDADE SEM-RELIGIÃO: O CULTIVO DA QUALIDADE HUMANA *
}

\author{
Spirituality without religion - the cultivation of human quality
}

José Álvaro Campos Vieira **

Flávio Senra ***

Resumo: O presente artigo reúne contribuições para o pensar sobre espiritualidades sem religião, não religiosas ou laicas. Por um lado, são abordados os sentidos de espiritualidades autônomas e independentes da crença, do corpo doutrinário e da organização comunitária representadas por instituições religiosas. Por outro lado, a reflexão versa sobre o cultivo da qualidade humana e da qualidade humana profunda a partir de uma concepção antropológica não-dual, segundo a qual o animal humano, como animal de fala, acessa a realidade e a modela como dimensão relativa às suas necessidades e como dimensão para além das suas necessidades. Ainda que nosso horizonte nos conduza a uma necessária superação dos termos religião e espiritualidade, considerados como fruto de projetos axiológicos não mais adequados a sociedades marcadas por um intenso processo de mudança constante, tais como as contemporâneas sociedades de conhecimento e de inovação, para o tratamento da questão, consideraremos ser adequado tratar alguns conceitos-chave de uma concepção tradicional sobre esses termos. Nesse sentido, procuramos apresentar, ainda que brevemente, alguma delimitação sobre esses termos em nosso trabalho. $O$ objetivo principal, contudo, é problematizar a questão da espiritualidade sem religião como

\footnotetext{
* Artigo recebido em 15/11/2020 e aprovado para publicação em 20/11/2020.

** Doutor e Mestre em Ciências da Religião pelo Programa de Pós-graduação em Ciências da Religião pela Pontifícia Universidade Católica de Minas Gerais. Bolsista CAPES (2014-2019). *** Doutor com estágio pós-doutoral em Filosofia pela Universidade Complutense de Madri. Mestre em Ciência da Religião pela Universidade Federal de Juiz de Fora. Docente do Departamento de Ciências da Religião na Pontifícia Universidade Católica de Minas Gerais. Bolsista de Produtividade em Pesquisa pelo CNPq (2017-atual).
} 
cultivo da qualidade humana à luz da teoria reconhecida como epistemologia axiológica, elaborada pelo pensador Marià Corbí. Questionamos o sentido de espiritualidade como decorrente da condição humana em sentido tradicional, a partir da consideração de que, fundamentalmente, o animal humano deva ser compreendido como um ser de linguagem. Como aponta a teoria corbiniana, o animal que fala, como ser necessitado, possui como mecanismo de sobrevivência atuar como um modelador da realidade e, nesse sentido, se processa o acesso não dual à dimensão absoluta do real (DA) e a dimensão relativa do real (DR). Nesse horizonte teórico-prático, entendemos por espiritualidade, [considerando-a especificamente como o cultivo da qualidade humana e da qualidade humana profundal, o processo decorrente de um projeto axiológico coletivo, que proporciona a realização da pessoa a partir do interesse incondicional pela realidade, do distanciamento e do silenciamento (IDS); cultivados como indagação livre, comunicação e serviço mútuo (ICS).

Palavras-chave: Espiritualidade sem religião. Qualidade humana profunda. Marià Corbí.

Abstract: This article gathers contributions to the understanding of spirituality without religion, either non-religious or secular. On the one hand, it addresses the significance of autonomous spiritualities that are independent from the beliefs, doctrinal body and community organization of religious institutions. On the other hand, it reflects on the cultivation of the human quality and the profound human quality, from a non-dual anthropological conception whereby the human animal, a talking animal, accesses reality and models it both as a dimension linked to needs and as one that goes beyond them. Our approach leads us to the necessity of overcoming the terms religion and spirituality, considered as the fruit of axiological projects no longer suitable for societies marked by an intense process of constant change, such as the contemporary knowledge societies and innovation societies. However, to deal with the issue, we consider appropriate to examine some key concepts from their traditional sense. Consequently, this study tries to present, though briefly, some of their delimitations. The main objective is to problematize the issue of spirituality without religion as a cultivation of human quality in light of the theory recognized as axiological epistemology, developed by the thinker Marià Corbí. We question the sense of spirituality as deriving from the human condition in its traditional sense, by considering that the human animal must fundamentally be understood as a being of language. As Corbí's theory points out, the survival mechanism of the speaking animal, as a being in need, works as a shaper of reality, processing, therefore, the non-dual access to the absolute dimension of reality (AD) and the relative dimension of reality (RD) . In this theoretical-practical apporoach, we specifically understand spirituality as the cultivation of human quality - the profound human quality, the process resulting from a collective axiological project which provides the realization of the person from the unconditional interest in reality, as well as from distance and silence (IDS); cultivated as free inquiry, communication and mutual service (ICS).

Keywords: Spirituality without religion. Deep human quality. Marià Corbí 
O convite que os mestres fazem para viver esta outra dimensão da realidade não é um convite para se submeter e acreditar, mas um convite para se verificar por si próprio.

$(\text { Marià Corbí) })^{1}$

\section{Introdução}

A investigação sobre o termo espiritualidade e sobre o termo religião é um longo capítulo na trajetória das diversas disciplinas que se dedicam aos estudos da religião. Infelizmente, nesse trabalho não teremos condições de percorrer essa trajetória em sua amplitude e profundidade. $\mathrm{O}$ volume de trabalhos é imenso e a variedade de abordagens e tendências superam muitas dezenas de possibilidades. Além disso, para além do campo acadêmico, o leque de pesquisas levantado pelas Ciências da Religião, a partir de cujas investigações podemos chegar a descrições empíricas sobre experiências religiosas concretas, igualmente demonstra uma multiplicidade de possibilidades de usos do termo espiritualidade.

O termo espiritualidade evoca a noção de respiração, foi cunhado na cultura grega (pneuma) e chegou até nós a partir da tradução latina (spiritus). Como lembra Sam Harris², a partir das superstições medievais o termo passou até mesmo a expressar a crença em almas imateriais, em seres sobrenaturais e em fantasmas. Para além dessa visão que nos parece bastante reduzida do termo, o que mais faz pensar deve ser o reconhecimento de que sobre o termo recai uma larga trajetória de abordagem segundo uma antropologia dualista, a qual atravessa o uso do termo ao longo da história. Os estudos mais recentes, os quais associam espiritualidade à busca de sentido, nem sempre parecem estar livres dessa antropologia calcada em epistemologia mítica, conforme explicitaremos a partir da teoria de Marià Corbí. ${ }^{3}$

Considerando os desenvolvimentos recentes do campo religioso e, em particular, como observação e análise da experiência de pessoas que se afirmam não afiliadas a alguma instituição religiosa (pessoas sem religião), temos nos perguntado pelo que pode significar o pensar uma espiritualidade não religiosa, ou seja, a busca de qualidade humana e de qualidade humana profunda para além de uma epistemologia mítica. ${ }^{4}$

${ }^{1}$ CORBÍ, Marià. Religión sin religión. Madrid: PPC, 1996. p. 43.

${ }^{2}$ Cf. HARRIS, Sam. Waking up. Searching for spirituality without religion. New York: Simon \& Schuster, 2014.

${ }^{3}$ Cf. CORBÍ, Marià. Proyectos colectivos para sociedades dinámicas. Principios de Epistemología Axiológica. Barcelona: Herder, 2020b.

${ }^{4}$ Cf. CORBÍ, Marià. Reflexiones sobre la cualidad humana en una época de cambios. Barcelona: Verloc/CETR, 2012. Cf. CORBÍ, Marià. El gran olvido: la gratuidad del vivir. Principio de Epistemología Axiológica 6. Madrid: Ed. Bubok, 2020a. 
Pensamos de início em espiritualidade sem religião como qualquer espiritualidade regulada e experienciada fora de marcos institucionais, doutrinais, com participação comunitária em sistemas de atos. ${ }^{5}$ Trata-se, portanto, de uma espiritualidade autônoma em relação ao controle das instituições; independente de doutrinas, de crenças e de adesão aos sistemas de atos. Compreendemos que esse fato, observado a partir de pessoas sem religião, deve ser problematizado não apenas como consequência do processo de desinstitucionalização da crença ou de individualização das experiências de fé. Do ponto de vista da epistemologia axiológica, a base do que se convencionou nomear espiritualidade é reconfigurada a partir da compreensão de que o animal humano, como animal de fala, é um modelador da realidade. É por esse meio e por essa razão que o animal humano se abre para um duplo acesso do real, afirma o autor que iremos abordar nesse trabalho, o epistemólogo Marià Corbí.

O trabalho está organizado em três momentos, perfazendo o caráter empírico-descritivo e sistemático da presente abordagem. No primeiro item do artigo serão delimitados os modos como alguns dos conceitos-chave da nossa reflexão têm sido comumente abordados. A seguir, considerando a experiência concreta de audição de 45 pessoas sem religião, material colhido para a tese doutoral com a qual estiveram envolvidos os autores, apresentam-se alguns aspectos característicos da espiritualidade sem religião. O terceiro item do presente artigo abordará a posição do epistemólogo Marià Corbí, quem propõe pensar o que se costuma nomear espiritualidade, enquanto cultivo da qualidade humana e da qualidade humana profunda, sob o viés da teoria da epistemologia axiológica. O momento atual das contemporâneas sociedades de conhecimento e de inovação, em oposição à epistemologia mítica das religiões e ideologias, exige uma nova abordagem para esse cultivo.

\section{O que se convencionou reconhecer como espiritualidade e o que podemos compreender como espiritualidade sem religião}

Uma visão tradicional compreende a espiritualidade como algo decorrente da atividade do espírito. Tal atividade é concebida como natural a todo ser humano, algo que lhe é dado e que lhe é próprio.

Em círculos de debate não atravessados por componentes religiosos, especialmente em organizações, como elencou, em pesquisa recente, Jonathan

${ }^{5}$ Cf. SENRA, Flávio. Espiritualidade não religiosa. In. RIBEIRO, Claudio de Oliveira; ARAGÃO, Gilbraz; PANASIEWICZ, Roberlei. Dicionário do Pluralismo Religioso. São Paulo: Ed. Recriar, 2020b. p. 71-77. 
Félix de Souza, ${ }^{6}$ espiritualidade é também assumida como maneira de pensar e como busca de sentido. Em pesquisas sobre espiritualidade e saúde, como investiga Mary Rute Gomes Esperandio, ${ }^{7}$ também se evidencia a espiritualidade como busca de sentido. Tal processo, evidenciam esses estudos, independe de crença e de não-crença. O programa de sentidos, ações e metas do ser humano para consigo e para com o seu entorno compõem um projeto de vida com sentido.

A esse respeito, destaca o teólogo Leonardo Boff,

Colocar questões fundamentais e captar a profundidade do mundo, de si mesmo e de cada coisa constitui o que se chamou de espiritualidade. Ela se deriva de espírito. Espírito [...] não é uma parte do ser humano. É aquele momento pleno de nossa totalidade consciente, vivida e sentida dentro de outra totalidade maior que nos envolve e nos ultrapassa: o universo das coisas, das energias, das pessoas, das produções histórico-sociais e culturais. Pelo espírito captamos o todo e a nós mesmos como parte e parcela desse todo. ${ }^{8}$

Nessa perspectiva, a espiritualidade costuma ser pensada como uma dimensão antropológica fundamental, algo que, apesar de ser independente de qualquer instituição ou doutrina religiosa é reconhecida como uma dimensão a ser cultivada, dado que a todo ser humano é facultada a pergunta pelo sentido de sua existência e do mundo em que se encontra. Para o atendimento dessa pergunta pelo sentido é comum identificarmos o reconhecimento da espiritualidade como dimensão imprescindível à realização e à integridade da pessoa humana.

A problematização dessa maneira de compreender a espiritualidade será apresentada mais adiante na perspectiva da epistemologia axiológica de Marià Corbí. Por ora, precisamos ainda caracterizar um segundo termo, a

${ }^{6}$ Cf. SOUZA, Jonathan Felix de. Inteligência espiritual: um estudo sobre o despertar de uma espiritualidade não religiosa como qualidade humana profunda nas organizações. 137f. Dissertação (Mestrado) - Pontifícia Universidade Católica de Minas Gerais, Programa de Pós-Graduação em Ciências da Religião, Belo Horizonte, 2020.

${ }^{7}$ Destacamos os seguintes trabalhos: AUGUST, Hartmut.; ESPERANDIO, Mary Rute Gomes. Apego a Deus: revisão integrativa de literatura empírica. Horizonte - Revista de Estudos de Teologia e Ciências da Religião, v. 17, n. 53, p. 1039, 31 ago. 2019. ESPERANDIO, Mary Rute Gomes et al. Coping Religioso/Espiritual na Antessala de UTI: Reflexões sobre a Integração da Espiritualidade nos Cuidados em Saúde. Interações, v. 12, n. 22, p. 303-322, 28 dez. 2017. ESPERANDIO, Mary Rute Gomes et al. Religiosidade/espiritualidade (R/E) em profissionais/ trabalhadores da saúde. Interações, v. 10, n. 18, p. 195-209, 31 dez. 2015. ESPERANDIO, Mary Rute Gomes. Espiritualidade no contexto da saúde: uma questão de saúde pública? In.: LEMOS, Carolina Teles; MARTINS FILHO, José Reinaldo F. Religião, espiritualidade e saúde: os sentidos do viver e do morrer. Belo Horizonte: Editora Senso, 2020. HEFTI, René; ESPERANDIO, Mary Rute Gomes. The Interdisciplinary Spiritual Care Model: A holistic Approach to Patient Care. Horizonte - Revista de Estudos de Teologia e Ciências da Religião, v. 14, n. 41, p. 13-47, 31 mar. 2016.

${ }^{8}$ BOFF, Leonardo. Crise. Oportunidade de crescimento. Campinas: Verus, 2002. p. 56. 
saber, o de espiritualidade sem religião ou comumente apresentada como espiritualidade não religiosa.

Iniciemos por remarcar que, em uma época marcada pela individualização e pelo egocentramento, a espiritualidade tende a ser caracterizada como uma orientação discernida e assumida efetivamente pelo próprio indivíduo. No entanto, nem sempre se observa abertura desse indivíduo para uma perspectiva relacional, uma experiência de interdependência e, ademais, processo tecido em diálogo com a sabedoria dos antepassados. ${ }^{9}$ A esse respeito, antecipamos uma consideração de Marià Corbí, segundo a qual, as tradições de sabedoria são uma fonte de sentido e de sabedoria para o cultivo da qualidade humana e da qualidade humana profunda. Embora constate que as religiões nas sociedades de conhecimento e de inovação estejam em processo de declínio, o autor admite que não podemos depreciar ou desconsiderar o que há de valioso no legado das grandes tradições. ${ }^{10}$

Em particular, na expressão espiritualidade sem religião somos estimulados a indagar sobre o que pode ser compreendido como religioso. Reconhecemos que a religião e, subsequentemente, o religioso sejam termos ao mesmo tempo limitados e circunscritos a uma específica tradição, tal como destaca Greschat. ${ }^{11}$ Por sua vez, os estudos sobre religião não foram capazes de produzir uma conceituação suficientemente abrangente sobre o fenômeno. ${ }^{12}$ Max Weber também manifestou a dificuldade de se definir religião em um estudo sobre sociologia da religião, especificamente sobre os tipos de relações comunitárias religiosas. Para o sociólogo, "uma definição daquilo que «é» religião é impossível no início de uma consideração como a que segue, e, quando muito, poderia ser dada no seu final."13 Também nós nos deparamos com igual dificuldade para precisar o que seja religião em sentido amplo. Esta dificuldade pode ser minimizada quando nos referimos a fatos concretos, expressões particulares, passíveis de obser-

\footnotetext{
${ }^{9}$ Cf. CORBÍ, Marià. La sabiduría de nuestros antepasados para sociedades en tránsito. Principios de Epistemología Axiológica 2. Madrid: Ed. Bubok, 2013.

${ }^{10}$ Cf. CORBÍ, Marià. Proyectar la sociedad, reconvertir la religión. Los nuevos ciudadanos. Barcelona: Herder, 1992.

${ }^{11}$ Cf. GRESCHAT, Hans-Jürgen. O que é Ciência da Religião. São Paulo: Paulinas, 2005.

${ }_{12}$ Os estudos que se debruçam sobre religião demonstram com evidência a inexistência de uma posição unívoca em relação ao conceito religião. Ou seja, acerca de religião existem várias interpretações e entendimentos. Por exemplo, o que para um autor se enquadra perfeitamente na categoria religião, para outro isso pode não proceder. Religião é, de fato, um conceito impreciso e dúbio. Cf. VIEIRA, José Âlvaro Campos. Os sem-religião. Aurora de uma espiritualidade não religiosa. Belo Horizonte: Editora PUC Minas, 2018. STEIL, C. A.; TONIOL, R. A crise do conceito de religião e sua incidência sobre a antropologia. In: GIUMBELLI, E.; BÉLIVEAU; V. G. (orgs.). Religión, cultura y política en las sociedades del siglo XXI. Buenos Aires: Biblos, 2013. p. 137-158.

${ }^{13}$ WEBER, Max. Economia e Sociedade. Fundamentos da sociologia compreensiva. v. 1, 4. ed. São Paulo: Editora UNB, 2004. p. 279.
} 
vação empírica, explicitados em sistema de atos, doutrina, comunidade e sedimentação da experiência. ${ }^{14}$ Ademais, como afirmam Filoramo e Prandi, "se se quiser falar de religião, só se pode fazê-lo historicizando o termo, isto é, ligando-o a um atributo que o prende à história. De si, «religião» [...] não significa nada." ${ }^{15}$

Considerado, portanto, exclusivamente o campo sobre o qual sustentamos essa reflexão, sem nenhuma pretensão de universalismo ou reducionismo, podemos inferir que por espiritualidade sem religião ou espiritualidade não religiosa daquelas pessoas sem religião, a experiência da fé ou da crença em Deus é cultivada fora das fronteiras de alguma instituição e doutrina religiosas. ${ }^{16}$ Observou-se que a experiência da fé que demarcou nosso entendimento de espiritualidade sem religião podia conter elementos de uma tradição religiosa ou de várias tradições simultaneamente. $\mathrm{O}$ fenômeno demonstra que a experiência se processa sob o gerenciamento exclusivo de indivíduos apartados de vínculo institucional, de indivíduos desobrigados dos ditames doutrinais e da participação em rituais instituídos.

Nesse sentido, afirmamos que a espiritualidade sem religião pode ser definida nesse contexto como uma espiritualidade individual e individualizada, ou seja, ela não aponta apenas para a exclusividade individual da experiência espiritual, mas inclui, ademais, a individualização. Em outras palavras, o que se observa é que os indivíduos sem religião, além de não participarem de alguma instituição religiosa, ressignificam as crenças que mantêm e rejeitam aquelas que não têm mais sentido segundo os seus modos de pensar e de viver.

Fundamentalmente, manifesta-se, por um lado, o fenômeno da desinstitucionalização da crença e a decorrente desobrigação dos indivíduos sem religião face a qualquer instituição ou grupo religioso; e, por outro lado, a individualização das crenças religiosas, que inclui a rejeição ou a ressignificação de qualquer crença, segundo o crivo de cada indivíduo sem religião. Esses elementos demonstram que o âmbito da vida espiritual de pessoas sem religião está orientado de acordo com as aspirações e desafios reais e cotidianos. No horizonte da espiritualidade sem religião, tanto a experiência espiritual quanto as crenças que sustentam essa mesma experiência, se processam sob a medida de cada indivíduo. Dessa forma, podemos demarcar que a espiritualidade sem religião se desenvolve de

\footnotetext{
${ }^{14}$ Cf. GRESCHAT, Hans-Jürgen. O que é Ciência da Religião. São Paulo: Paulinas, 2005.

${ }^{15}$ FILORAMO, Giovanni; PRANDI, Carlo. As Ciências das Religiões. São Paulo: Paulus, 1999. p. 273.

${ }^{16}$ Cf. VIEIRA, José Álvaro Campos Vieira. Ensaio de espiritualidade não religiosa: estudo a partir de indivíduos sem religião em Belo Horizonte. 327f. Tese (Doutorado) - Pontifícia Universidade Católica de Minas Gerais, Programa de Pós-Graduação em Ciências da Religião, Belo Horizonte, 2020.
} 
acordo com os sentidos atribuídos, com o gosto e com as preferências de cada pessoa.

Pode-se, contudo, perguntar se a espiritualidade pode subsistir de forma autônoma e independente da religião. Ainda que se reconheça que espiritualidade seja uma experiência originária e que a religião seja uma criação decorrente de sua institucionalização, a história da humanidade demonstra que a espiritualidade se desenvolve por meio de um vínculo com determinada religião ou sistema de crenças. Contudo, a espiritualidade pode ser cultivada de forma separada de qualquer religião, quer seja em relação a alguma instituição religiosa, quer seja em relação a qualquer doutrina religiosa.

A espiritualidade não religiosa é uma espiritualidade autônoma, ou seja, é gerenciada a partir do discernimento e da experiência dos indivíduos, e não segundo as doutrinas, orientações práticas e sistemas de atos vinculados a uma instituição religiosa. Rompe-se com o modelo a partir do qual é a instituição que detém o poder de gerenciamento da espiritualidade. $\mathrm{Na}$ perspectiva dos sem-religião são os indivíduos que delegam a si mesmos esse poder de gerenciamento. Nesse sentido é que afirmamos se tratar de uma espiritualidade autônoma.

Além disso, ponderamos que a espiritualidade sem religião seja independente em razão de se tratar de algo com uma força vital própria, capaz de se desenvolver sem necessidade de um vínculo a alguma doutrina religiosa, participação em alguma comunidade ou sistema de atos. Ainda que a espiritualidade dos indivíduos possa estar moldada conforme o conteúdo definido pela doutrina religiosa, temos percebido, considerado o trabalho de campo com pessoas sem religião, a emergência de uma espiritualidade regulada segundo os sentidos instituídos pelos próprios indivíduos. Dado que o arcabouço conceitual e de sentido da espiritualidade está definido pelo próprio indivíduo, e não por outrem, alegamos se tratar de a espiritualidade sem religião uma espiritualidade independente.

\section{Traços de uma espiritualidade sem religião}

Conforme fenômeno demonstrado e analisado por Vieira, ${ }^{17}$ pessoas sem religião tendem a experimentar suas crenças e sua fé ao modo do que temos nomeado como espiritualidade sem religião, ou seja, creem sem vínculo

${ }^{17}$ Cf. VIEIRA, José Álvaro Campos Vieira. Ensaio de espiritualidade não religiosa: estudo a partir de indivíduos sem religião em Belo Horizonte. 327f. Tese (Doutorado) - Pontifícia Universidade Católica de Minas Gerais, Programa de Pós-Graduação em Ciências da Religião, Belo Horizonte, 2020. 
com o conteúdo doutrinário, sem vínculo com o sistema de atos (ritos), sem vínculo comunitário. Enfim, sem vínculo reconhecido com instituições religiosas. Vejamos alguns traços característicos dessa experiência. ${ }^{18}$

\subsection{Uma espiritualidade sob o controle do indivíduo}

Concordamos com os estudos que afirmam ser nosso tempo marcado pelo individualismo. Bauman se refere à situação do nosso tempo como "virada axial" ${ }^{19}$ Lipovetsky destaca, por sua vez que, na atualidade, "tudo concorre para a promoção de um individualismo puro [...] para a valorização geral do indivíduo" ${ }^{20}$ Nesse sentido, compreendemos que a situação das pessoas não afiliadas (sem religião) demonstra a relação desse fenômeno com o espírito de época. O campo evidenciou que cada indivíduo sem religião determina valor e sentido para a sua experiência, ou seja, o discernimento individual se sobrepõe ao que é estabelecido pela doutrina, pela instituição e pela liderança religiosa.

A ideia de uma espiritualidade individualizada se reforça quando se constata que a espiritualidade dos sem-religião tem como fundamento o discernimento e a vontade dos próprios indivíduos, e não alguma tradição familiar, instituição religiosa ou preceitos doutrinários. E mesmo que alguns sem-religião afirmem crer em Deus, essa crença está demarcada pelos sentidos que lhe confere o próprio indivíduo. Trata-se de uma espiritualidade em que cada indivíduo se torna o próprio fundamento da experiência.

Na visão de Marcel Gauchet, ${ }^{21}$ por exemplo, o fortalecimento da autonomia do indivíduo provoca a mudança da religião institucionalizada para a religião individualizada, a ponto de o lugar privilegiado da experiência religiosa ser reduzida ao âmbito individual. Segundo Carlos Steil, ${ }^{22}$ a auto-

\footnotetext{
${ }^{18}$ Vieira aplicou um questionário estruturado como parte de sua tese de doutoramento no Programa de Pós-graduação em Ciências da Religião da PUC Minas sob orientação do coautor. O trabalho, que cumpriu todos os requisitos e foi aprovado pelo Comitê de Ética em Pesquisa, recebeu a contribuição de quarenta e cinco pessoas identificadas como sem religião, residentes na região do Taquaril, zona leste de Belo Horizonte/MG. A região, segundo dados do Censo 2010 do IBGE, possui número superior a $60 \%$ da média nacional de sem-religião. Cf. VIEIRA, José Álvaro Campos Vieira. Ensaio de espiritualidade não religiosa: estudo a partir de indivíduos sem religião em Belo Horizonte. 327f. Tese (Doutorado) - Pontifícia Universidade Católica de Minas Gerais, Programa de Pós-Graduação em Ciências da Religião, Belo Horizonte, 2020.

${ }^{19}$ BAUMAN, Zygmunt. A cultura no mundo líquido moderno. Rio de Janeiro: Zahar, 2013. p. 17. ${ }^{20}$ LIPOVETSKY, Gilles. A era do vazio. Ensaios sobre o individualismo contemporâneo. Barueri: Editora Manole, 2005. p. 34.

${ }^{21}$ Cf. GAUCHET, Marcel. Le désenchantement du monde: une histoire politique de la religion. Paris: Gallimard, 1985. p. 393.

${ }^{22}$ Cf. STEIL, Carlos. A modernidade fragmentou o campo religioso e fez emergir uma diversidade de religiões. Cadernos IHU em formação, São Leopoldo, ano VIII, n. 43, p. 83-86, 2012.
} 
nomia dos indivíduos na construção das identidades religiosas é um dos fatores que propicia a mudança da religião tradicional para a religião de indivíduos. Pierre Sanchis ${ }^{23}$ também ressalta, a propósito desse diagnóstico, que a emergência do indivíduo fomentará o surgimento de religiosidades individuais. Enfim, se pensarmos o indivíduo sem religião com o status de valor supremo, como fundamento e gestor de sua espiritualidade, e desobrigado de qualquer instituição e preceito religiosos, somos induzidos a pensar ou deduzir que uma espiritualidade não religiosa se apresenta como consequência de uma cultura fundada no individualismo como padrão.

\subsection{Uma espiritualidade desinstitucionalizada e individualizada}

A centralidade do indivíduo nos incita a pensar o impacto consequente dessa conduta na percepção das pessoas a respeito das instituições e das crenças religiosas.

Uma vez que o indivíduo não é mais o meio de uma finalidade exterior, mas, sim, é considerado, e se considera, como finalidade última, as instituições sociais perdem sua aura sagrada, tudo aquilo que procede de uma transcendência inviolável e se revela em uma heteronímia de natureza, encontra-se, em um prazo maior ou menor, minado por uma ordem social e ideológica cujo centro não é mais o além, mas o próprio indivíduo autônomo. ${ }^{24}$

Perante a autonomia consolidada do indivíduo, a sacralidade operacional das instituições religiosas é revogada pelos sem-religião. Os sem-religião, livres do controle institucional, cultivam sua espiritualidade do modo que lhes parece mais apropriado e condizente. Isso nos remete à ideia de "fé à la carte" ${ }^{25}$ segundo a qual cada indivíduo pode escolher a sua fé, distinguir entre diferentes cosmovisões e espiritualidades, ideias e práticas.

Como reconhece Taylor, a experiência espiritual "[...] deve não só ser a minha escolha, mas deve falar-me, deve fazer sentido em termos do meu desenvolvimento espiritual, como eu o entendo." ${ }^{26}$ Os indivíduos são provocados a transformar sua vida cotidiana num processo contínuo de escolhas, tarefas, experiências, sem, realmente, se fixarem em alguma dessas possibilidades.

Essa espiritualidade desobrigada de instituição, tradição e doutrina decorre da autonomia adquirida pelos indivíduos que, por sua vez, viabiliza a

\footnotetext{
${ }^{23}$ Cf. SANCHIS, Pierre. Pluralismo, transformação, emergência do indivíduo e de suas escolhas. Cadernos IHU em formação, São Leopoldo, ano VIII, n. 43, p. 36-39, 2012.

${ }^{24}$ LIPOVETSKY, Gilles. A era do vazio. Ensaios sobre o individualismo contemporâneo. Barueri: Editora Manole, 2005. p. 184.

${ }^{25}$ COMTE-SPONVILLE, André; FERRY, Luc. A sabedoria dos modernos. Dez questões para o nosso tempo. Lisboa: Instituto Piaget, 2016. p. 235.

${ }^{26}$ TAYLOR, Charles. A era secular. Lisboa: Instituto Piaget, 2012. p. 509.
} 
desinstitucionalização da experiência espiritual e a individualização das crenças religiosas. Teixeira aduz que "junto com a desinstitucionalização crescente, expressão da crise das instâncias sólidas que fundavam, enquadravam e regulavam o campo das experiências religiosas, instala-se a quebra de transmissão da memória religiosa." ${ }^{27} \mathrm{Na}$ perspectiva da socióloga francesa Danièle Hervieu-Léger, ${ }^{28}$ a quebra na conservação das tradições religiosas ocasiona algo preocupante para as instituições, pois toda instituição necessita manter viva a transmissão dos seus valores, dos seus bens simbólicos, dos seus saberes. Segundo a pesquisadora, "a transmissão ${ }^{29}$ é o próprio movimento pelo qual a religião se constitui como religião através do tempo." ${ }^{30}$ Desse ponto de vista, entende-se que quanto mais se acentua o distanciamento entre os indivíduos e as tradições religiosas, mais se aprofunda a crise das instituições religiosas e, consequentemente, das religiões, pois sua doutrina e respectivas crenças sujeitam-se a serem rejeitadas ou ressignificadas pelos próprios indivíduos. Acompanhando essa perspectiva, reconhecemos que os sem-religião desenvolvem uma espiritualidade que se configura como processo de desinstitucionalização, além do processo de individualização acima descrito.

Leila Amaral, ${ }^{31}$ se refere a uma espiritualidade ajustada por experiências que aludem a um "sagrado sem lugar". Quando ouvidas as pessoas sem religião a respeito de algumas de suas experiências de fé, recordamos o que a antropóloga explicita a respeito dessa realidade que "não significa negação ou vazio de sagrado. Expressa, ao contrário, a onipresença do sagrado em todas as dimensões da experiência humana cotidiana." ${ }^{32}$ No testemunho dos sem-religião pesquisados preserva-se do legado das tradições, o vínculo com o que reconhecem como Deus e a prática da oração

${ }^{27}$ TEIXEIRA, Faustino. Experiência religiosa: abordagem das Ciências da Religião. Disponível em: http://theologicalatinoamericana.com/?p=203. Acesso em: 29 jul. 2019.

${ }^{28}$ HERVIEU-LÉGER, Danièle. O peregrino e o convertido. A religião em movimento. Petrópolis: Vozes, 2008.

${ }^{29}$ Para os estudos sobre memória e transmissão no pensamento de Danièle Hervieu-Léger, recomendamos o trabalho de Rivera e Barroso. Cf. RIVERA, Paulo Barrera. Tradição, transmissão e emoção religiosa. Sociologia do protestantismo contemporâneo na América Latina. São Paulo: Olho d'Água, 2001. BARROSO, Victor Breno Farias. Modernidade religiosa: memória, transmissão e emoção no pensamento de Danièle Hervieu-Léger. São Paulo: Fonte Editorial, 2014.

${ }^{30}$ HERVIEU-LÉGER, Danièle. O peregrino e o convertido. A religião em movimento. Petrópolis: Vozes, 2008. p. 28. Contribui para o aprofundamento dessa questão os estudos sobre memória individual e memória coletiva desenvolvidos por Halbwachs. Cf. HALBWACHS, Maurice. A memória coletiva. São Paulo: Centauro, 2003.

${ }^{31}$ Cabe aqui destacar que Leila Amaral se refere à diversidade de experiências, tanto religiosas quanto espirituais da sociedade brasileira. A autora realça a cultura religiosa descentralizada e errante, no sentido de que não há influência coercitiva de sistemas normativos frente à ação desprendida dos indivíduos.

${ }^{32}$ AMARAL, Leila. Cultura religiosa errante. O que o Censo de 2010 pode nos dizer além dos dados. In: TEIXEIRA, Faustino; MENEZES, Renata (orgs.). Religiões em movimento. O Censo de 2010. Petrópolis: Vozes, 2013, p. 104. 
pessoal. Porém, esse testemunho é acompanhado da reação à submissão a qualquer instância que desconsidere ou invalide sua individualidade. Como destaca Boff, ${ }^{33}$ sendo capaz de se autoafirmar, cada indivíduo faz a sua síntese a partir de um centro que é sua individualidade irrepetível.

Rompe-se, nessa experiência concreta dos sem-religião com a força impessoal exercida pela ou por uma instituição social, no caso, a religião, sobre o indivíduo como compreendia Durkheim ${ }^{34}$ quando tratava da religião. No lugar dessa percepção surge uma busca personalizada sob a influência de uma motivação intrínseca ao próprio indivíduo. Trata-se, como explicita Taylor, "de uma procura pessoal e pode ser facilmente codificada na linguagem da autenticidade", ${ }^{35}$ ou seja, a busca do encontro consigo mesmo.

\subsection{Fim da ideia dogmática de Deus}

$\mathrm{Na}$ atualidade, qualquer indivíduo que aspira a se autoafirmar está convencido de que tem de descobrir a

“[...] maneira de realizar a sua humanidade e de que é importante encontrar e viver de acordo com o seu caminho, em oposição à rendição ao conformismo com um modelo imposto do exterior, pela sociedade ou pela geração anterior, ou pela autoridade política ou religiosa." ${ }^{\prime 36}$

A experiência colhida dos sem-religião parece apontar para essa mesma aspiração. Desobrigados de qualquer instituição e doutrina religiosas, alguns desses elementos serão dispensados e outros reformulados por esses indivíduos. É nesse processo que julgamos pertinente destacar e refletir sobre a ideia de Deus para os sem-religião.

Ao indagar a respeito de possíveis implicações que decorrem da individualização da ideia de Deus, pergunta-se pela ideia de Deus presente para esse grupo heterogêneo de indivíduos. Relativamente à noção que têm de Deus, os indivíduos sem religião pesquisados destacam que se trata de algo acessivel a todos, presente em qualquer lugar. Reforçam que Deus não é propriedade de alguma instituição e que, para acreditar em Deus, não é necessária uma religião. Destacam que a ideia de Deus não lhes parece regulada pelas tradições religiosas, por suas respectivas autoridades ou corpo de especialistas, mas pelos próprios indivíduos.

${ }^{33}$ Cf. BOFF, Leonardo. Crise. Oportunidade de crescimento. Campinas: Verus, 2002.

${ }^{34}$ DURKHEIM, Émile. As formas elementares de vida religiosa: o sistema totêmico na Austrália.

2. ed. São Paulo: Paulus, 1989.

35 TAYLOR, Charles. A era secular. Lisboa: Instituto Piaget, 2012. p. 533.

36 TAYLOR, Charles. A era secular. Lisboa: Instituto Piaget, 2012. p. 499. 
As pessoas sem religião rompem com a pretensão de controle da experiência com o que reconhecem como Deus. ${ }^{37}$ Não obstante, sugerem os entrevistados que essa experiência esteve refém do controle exercido pelos autonomeados representantes de Deus. Contra essa pretensão de controle de Deus se manifestam os sem-religião, ou seja, contra o poder pretendido de gerenciamento do bem religioso. Se, em perspectiva religiosa, a ideia de Deus está estabelecida segundo uma tradição, em uma perspectiva não religiosa, com o não reconhecimento do poder de gerenciamento das instituições, a noção que se tem de Deus passa inevitavelmente pelo gerenciamento dos próprios indivíduos.

Como, oportunamente, observa Charles Taylor também no cenário analisado encontramos que "uma maior quantidade de pessoas expressa crenças religiosas que se desviam da ortodoxia cristã." ${ }^{38}$. Em outras palavras, sob o controle de indivíduos desvinculados e desobrigados das instituições religiosas, a ideia de Deus é potencializada por expressões de fé individuais.

Reforcemos que a pessoa que se identifica como sem religião, em geral é alguém que mantém a crença em Deus. Porém, essa pessoa se mantém desvinculada da instituição religiosa. Ao considerarmos a pessoa que mantém a noção e a experiência de Deus em harmonia com o cânone de uma tradição, mediante reconhecimento de um corpo doutrinário, de uma vivência comunitária e de um sistema de atos compartilhado, consideramos estarmos diante de uma espiritualidade religiosa. No caso de a pessoa experimentar o que reconhece como Deus remodelado por ela mesma ponderamos que aí se manifesta o que pode ser identificado como uma espiritualidade não religiosa. Esta, por sua vez, além de caracterizar-se como uma espiritualidade desinstitucionalizada, é também identificada como uma espiritualidade individualizada.

\section{Cultivo da qualidade humana profunda}

O estudo sobre espiritualidade não religiosa de pessoas sem religião nos conduz ao pensamento do epistemólogo Marià Corbí. Trata-se de um autor que pensa a situação da religião e da espiritualidade no contexto

\footnotetext{
${ }^{37}$ Como destacou o filósofo Henrique Cláudio de Lima Vaz, a experiência de Deus não é um luxo espiritual e sequer uma construção intelectual. A experiência de Deus é uma experiência universal, está acessível a todos. Trata-se de uma experiência de fato, cujo cumprimento é viável e efetivo. Para o filósofo, a experiência de Deus é uma experiência do Sentido Radical. Não se trata de mais uma experiência no conjunto das experiências humanas. A experiência de Deus é uma experiência que se reflete vivamente em todas as dimensões da vida daquele ou daquela que experiencia. Cf. VAZ, Henrique Cláudio de Lima. Escritos de Filosofia. Problemas de fronteira. São Paulo: Loyola, 1986.

${ }^{38}$ TAYLOR, Charles. A era secular. Lisboa: Instituto Piaget, 2012. p. 539.
} 
das modernas sociedades de conhecimento. Estas sociedades, entende o autor, são aquelas que "vivem e prosperam na contínua criação de ciência e tecnologia de apoio mútuo, e através deles, da criação de novos produtos e serviços." ${ }^{\prime 39}$.

A abordagem realizada por Marià Corbí se situa, fundamentalmente, no âmbito da teoria da epistemologia axiológica. Trata-se de uma abordagem que vem sendo construída pelo autor ao longo de sua trajetória intelectual. Já são mais de quarenta anos construindo a sua teoria, a qual pode ser encontrada em sua ampla produção bibliográfica e nas várias atividades do Centro de Estudos de Tradição de Sabedoria, o CETR, com sede em Barcelona.

A teoria da epistemologia axiológica analisa os modelos organizacionais das sociedades agrícolas, das sociedades industriais e das sociedades do conhecimento. Quanto a seu objetivo, a epistemologia axiológica deve ser "capaz de gerar uma teoria de valor e das suas transformações, para encontrar as leis que regem estas construções e transformações, a fim de poder responder à nossa situação axiológica atual" ${ }^{40} \mathrm{O}$ objetivo é compreender como em cada uma das sociedades acima mencionadas são construídos os projetos axiológicos coletivos (PAC), de acordo com padrões de interpretação que formam os seus sistemas de valores humanos. A partir deste entendimento, Corbí desenvolve a sua teoria, que interpreta a axiologia e a religião como frutos da cultura, ou seja, como realidades geradas a partir dos modelos de vida de cada época.

Corbí tem se dedicado ao estudo da crise axiológica contemporânea, uma crise resultante das transformações que ocorrem nas modernas sociedades de conhecimento e de inovação. Para o autor, essa é uma das maiores crises pelas quais a humanidade está atravessando em sua história. Através da teoria da epistemologia axiológica, Corbí procura compreender como se formam os sistemas axiológicos nas sociedades humanas com o intuito de elaborar uma teoria sobre o valor. A partir dessa teoria, o epistemólogo tenciona propor um caminho para auxiliar os indivíduos e grupos no enfrentamento da crise axiológica e dos desafios atuais.

Para Corbí, o padrão das sociedades pré-industriais está ameaçado pelos atuais modelos de sociedades do conhecimento. O diagnóstico da realidade se expressa em um conjunto de transformações por que passam as sociedades desde a primeira revolução industrial ocorrida na Europa e difundida pelo mundo através do processo de colonização e, posteriormente, pela globalização. Desde então, muitas e variadas mudanças tiveram lugar nas

\footnotetext{
${ }^{39}$ CORBÍ, Marià. Las sociedades de conocimiento y la calidad de vida. Principios de Epistemología Axiológica 5. Madrid: Ed. Bubok, 2017. p. 14.

${ }^{40}$ CORBÍ, Marià. El destino de las nuevas sociedades industriales está solo en nuestras manos. Horizonte: Belo Horizonte, v. 9, n. 23, p. 822, out./dez. 2011.
} 
nossas sociedades, considerada a ideia de diversidade cultural que não deixa de estar na base da posição teórica do autor. Nessa perspectiva, a revolução industrial introduziu um poderoso instrumento de transformação que se desenvolveu e deu origem, em nossos dias, ao novo padrão das sociedades do conhecimento e da inovação contínua.

De acordo com o ponto de vista prático da sua teoria sobre epistemologia axiológica, o novo padrão já não nos permite viver sob os princípios dos antigos padrões pré-industriais. A esperada urgência de transformação anda de mãos dadas com a noção de que este processo é imparável. Porém, entre o que é vivido e o que há de vir, não se pode necessariamente dizer que haja progresso na visão do autor.

A forma de proceder e de atuar características das sociedades pré-industriais, com todas as suas criações culturais, é enquadrada por Corbí na noção de submissão. Para Corbí, quanto às tradições religiosas, existe aqui um problema, ou seja, as tradições de sabedoria nasceram e se constituíram a partir de um padrão que já não é reconhecido nas sociedades modernas do conhecimento. Eles são como línguas mortas, afirma o epistemólogo, ou seja, já não se comunicam com as pessoas das modernas sociedades do conhecimento. Esse novo padrão, a nosso entender, sugere que o processo de individualização e de desinstitucionalização acima apresentados na pesquisa sobre os sem-religião, pode estar intimamente relacionado com essa transformação percebida pelo autor em tela.

Nas sociedades pré-industriais ou estáticas há, segundo Corbí, uma forma de compreender a religião limitando-a à condição de aliado das formas de submissão, controle e dominação. Destacamos acima o quanto para pessoas sem religião a instituição, a doutrina e o sistema de atos lhes pareciam parte de um sistema opressor, em relação ao qual desejam liberar-se até mesmo para vivenciar a sua crença com maior autenticidade. Corbí nos ajuda a compreender que no modelo de sociedades estáticas a noção de religião está associada à manutenção da obediência à autoridade para o controle ideológico. Quanto a isso, pessoas sem religião não deixam de insistir que não desejam vivenciar a sua crença no que reconhecem como Deus sob a tutela de quaisquer autoridades. ${ }^{41}$

O que a teoria de Corbí nos permite reconhecer é que o sistema de submissão e obediência se afirma a partir da estrutura típica das sociedades pré-industriais, um modelo incompatível com as modernas sociedades de conhecimento. Tal modelo de submissão sobre o qual se assenta o projeto axiológico coletivo reconhecido como religião pode ter se constituído a partir das sociedades agrícolas de irrigação, o que Corbí identifica como sociedades agrário-autoritárias.

${ }^{41}$ Cf. CORBÍ, Marià. Las sociedades de conocimiento y la calidad de vida. Principios de Epistemología Axiológica 5. Madrid: Ed. Bubok, 2017. 
Considerando que, para Corbí, ${ }^{42}$ o modo de sobrevivência define o padrão cultural, temos que considerar, por exemplo, que no momento em que as sociedades tinham o cultivo como ocupação central, sucedendo às sociedades de caçadores e de coletores, especialmente as de cultivo de irrigação, tornou-se necessário estruturar a vida a partir de valores como obediência, disciplina e coerção, uma vez que era necessário o controle de grandes massas de trabalhadores. Neste sentido, o autor compreende que a autoridade agrária depende da autoridade religiosa para obter o mais amplo controle da sociedade. Este modelo sustenta a relação entre autoridade e religião.

Destaque-se que, para Corbí, a religião é

um fato fundamentalmente axiológico e só pode existir se se apoiar em unidades semânticas carregadas de valor, ou seja, em unidades semânticas que, para além da possível referência objetiva, estabelecem comunhão de valores entre sujeitos e estabelecem módulos de interpretação da realidade de modo a criar significado na vida dos grupos humanos. E compreendemos pelo sentido da vida, valorizações e normas que determinam de forma inequívoca e absoluta o que vale e o que não vale, o que deve ser feito e o que deve ser evitado para viver e não morrer; valorizações e normas que se movem de forma eficaz para optar pela vida e não pela morte. ${ }^{43}$

Cabe, contudo, destacar que Corbí está preocupado com o legado das tradições dos nossos antepassados. ${ }^{44} \mathrm{O}$ conteúdo destas tradições é uma herança rica, mesmo no nosso tempo. Em Religião sem Religião, o autor afirma que "é urgente fazer um esforço individual e coletivo para resgatar a imensidade da riqueza das grandes tradições religiosas das novas condições culturais." ${ }^{45}$

Sob a ótica de Corbí, as religiões são edificadas como projetos axiológicos coletivos (PAC), próprios de sociedades pré-industriais. Se no quadro das sociedades pré-industriais, a religião foi entendida como "revelação divina", ${ }^{46}$ nas modernas sociedades do conhecimento, "nenhum PAC é revelação divina, nenhuma religião é exclusiva e única." ${ }^{47}$ Quando deixa

\footnotetext{
${ }^{42}$ Cf. CORBÍ, Marià. Análisis epistemológico de las configuraciones axiológicas humanas. La necesaria relatividad cultural de los sistemas de valores humanos: mitologías, ideologías, ontologías y formaciones religiosas. Salamanca: Ediciones Universidad de Salamanca, 1983. Cf. CORBÍ, Marià. Para uma espiritualidade leiga. Sem crenças, sem religiões, sem deuses. São Paulo: Paulus, 2010.

${ }^{43}$ CORBÍ, Marià. Análisis epistemológico de las configuraciones axiológicas humanas. La necesaria relatividad cultural de los sistemas de valores humanos: mitologías, ideologías, ontologías y formaciones religiosas. Salamanca: Ediciones Universidad de Salamanca, 1983. p. 50.

${ }^{44}$ Cf. CORBÍ, Marià. La sabiduría de nuestros antepasados para sociedades en tránsito. Principios de Epistemología Axiológica 2. Madrid: Ed. Bubok, 2013.

${ }^{45}$ CORBÍ, Marià. Religión sin religión. Madrid: PPC, 1996. p. 4.

${ }^{46}$ CORBÍ, Marià. Las sociedades de conocimiento y la calidad de vida. Principios de Epistemología Axiológica 5. Madrid: Ed. Bubok, 2017. p. 106.

${ }^{47}$ CORBÍ, Marià. Las sociedades de conocimiento y la calidad de vida. Principios de Epistemología Axiológica 5. Madrid: Ed. Bubok, 2017. p. 231.
} 
de ser submissão, a religião também deixa de ser "exclusiva e excluída (...) e torna-se acolhedora." ${ }^{\prime 4}$

Na obra Religião sem religião, afirma que a religião nas modernas sociedades do conhecimento será ensinada "em contextos fluidos de inovação e investigação livre onde só nós somos responsáveis pela construção dos nossos projetos e onde só nós lideramos as nossas construções." ${ }^{49}$ Neste horizonte, os ensinamentos dos antepassados mestres da sabedoria serão vividos independente do horizonte normativo da crença. Aqui também encontramos um estreito ponto de interseção com a experiência revelada pelas pessoas sem religião da pesquisa aqui analisada. O chamado processo de individualização vem sendo destacado como um dos traços que demarcam o perfil de pessoas sem religião em seu cultivo da fé. O que mantém de crença não se sujeita aos princípios doutrinários e institucionais, ou seja, são experiências que se tecem na liberdade de uma elaboração pessoal do conteúdo da própria vivência. Tal é o que podemos inferir dos testemunhos coletados naquela investigação.

Não obstante, identificamos que a maioria das pessoas sem religião não rompem de todo com a estrutura da crença, muito pelo contrário. Observamos que os sem-religião mantêm o que Corbí identifica como epistemologia mítica.

Os projetos axiológicos coletivos que estruturam a religião estão configurados pela epistemologia mítica. Na visão de Marià Corbí, a epistemologia mítica é a que considera as modelações que o animal humano produz através da linguagem como uma representação fidedigna da realidade. Elas podem ser concebidas como uma revelação dos deuses ou mesmo uma ideologia, filosofia ou ciência com iguais pretensões.

Ao ser permeada pela epistemologia mítica, a qual era adequada e eficaz para os indivíduos das sociedades pré-industriais, a religião, na contemporaneidade, torna-se ineficiente na construção de projetos para a vida individual e coletiva. Contudo, para o autor, o declínio da religião não aponta para o fim da experiência de cultivo da qualidade humana e da qualidade humana profunda. Segundo o autor,

Na maioria dos países desenvolvidos, a época das religiões já se acha à margem. No entanto, o que está morrendo não é a possibilidade de se viver a experiência absoluta da realidade, a experiência espiritual, mas uma maneira cultural, venerável e milenar, de fazê-lo. ${ }^{50}$

${ }^{48}$ CORBÍ, Marià. Religión sin religión. Madrid: PPC, 1996. p. 56.

${ }^{49}$ CORBÍ, Marià. Religión sin religión. Madrid: PPC, 1996. p. 43.

${ }^{50}$ CORBÍ, Marià. Para uma espiritualidade leiga. Sem crenças, sem religiões, sem deuses. São Paulo: Paulus, 2010. p. 168. 
As religiões como projetos axiológicos coletivos pré-industriais estão em crise. Tal afirmação pode soar equivocada para um contexto em que se nota a presença exaustiva da religião como é o caso brasileiro. Porém, como pondera o autor, as religiões estão em crise como verdades baseadas na recepção de valores de fora (ou acima), ou seja, heteronimicamente. Essa situação é repetidamente observada no relato de pessoas sem religião. Trata-se de um relacionar-se com a fé individual, de forma desinstitucionalizada no sentido aqui exposto. Os valores, os princípios, as noções religiosas têm valor para os sem-religião quando elaborados e reconhecidos no âmbito de sua subjetividade.

Não foi possível investigar nesse momento sobre o modo como tais pessoas sem religião efetivamente cultivam o que chamam ter fé, ou seja, a isso que, segundo o nosso referencial teórico, seria denominado cultivo da qualidade humana e da qualidade humana profunda. Em princípio, até que consigamos avançar mais no processo de investigação, o que está em curso, tomamos como hipótese que os sem-religião não chegam a uma elaboração da sua própria experiência para além da vivência de uma prática herdada de suas respectivas tradições religiosas. Nesse sentido, deveríamos destacar que o senso religioso ainda não é ele mesmo sem religião. Se formos seguir rigorosamente a proposta de Marià Corbí, necessitamos procurar pelo modo como pessoas sem religião cultivam IDS-ICS, ou seja, sobre como cultivam interesse, desprendimento e silenciamento (IDS), e, indagação, comunicação e serviço (ICS)..$^{51}$ Vejamos em que consiste o cultivo de IDS e ICS.

Segundo Corbí há uma qualidade humana quando há interesse na realidade, um interesse não egocêntrico; quando há desapego ou desprendimento das estruturas dos desejos; e quando há silenciamento dos desejos. Interesse, desprendimento e silenciamento (IDS), ao mesmo tempo em que forma uma tríade, se configura como uma unidade na qual estes três aspectos estão contidos, ou, ainda, também se pode dizer que é uma atitude com um aspecto triplo. Desta atitude depende a qualidade humana. IDS é qualidade humana. Quando cultivada em profundidade, fornece qualidade humana profunda. Isto era anteriormente chamado espiritualidade, entende Corbí.

IDS é uma atitude ou unidade em que três aspectos estão desenvolvidos e implícitos. Nas sociedades do conhecimento, IDS é vivido e cultivado através de outra tríade, explica o autor. O IDS é cultivado como indagação

\footnotetext{
${ }^{51}$ Tal investigação segue em curso no Grupo de Pesquisa Religião e Cultura, do Programa de Pós-graduação em Ciências da Religião, sob orientação de Flávio Senra tendo como membro da equipe o doutorando Jonathan Félix de Souza. Também participa desse projeto de investigação a pesquisadora Queralt Prat-i-Pubill, do grupo do CETR de Barcelona. Cf. PRAT-I-PUBILL, Queralt. Axiological knowledge in a knowledge driven world. Considerations for organizations. 173f. Tese (Doutorado) - Doctoral School of Organisation and Management Studies, Copenhagen, 2018.
} 
livre, contínua, individual e/ou coletiva e não como submissão (a uma revelação, a mestres ou a autoridades). IDS é também cultivada como comunicação e interdependência, uma comunicação orientada para a dimensão absoluta na qual indivíduos e grupos se constituem a si próprios como comunicação (comunicação de revelação que conduz à investigação contínua, comunicação de mestres das tradições de sabedoria e comunicação de tradições e textos de sabedoria). Finalmente, cabe destacar que o IDS nas sociedades do conhecimento é vivido como um serviço mútuo baseado na liberdade, voluntariedade e interdependência, ensina-nos o autor. Interesse, distanciamento e silenciamento (IDS) é vivido como indagação, comunicação e serviço (ICS).

Para Marià Corbí, qualquer atividade humana alicerçada nas três atitudes - interesse, distanciamento e silenciamento (IDS) será permeada pelo cultivo da qualidade humana. Ao conjunto dessas três atitudes, Marià Corbí denominou certa vez espiritualidade leiga (CORBÍ, 2010). O termo leigo alude aqui a uma forma de pensar, de avaliar, de interpretar e de atuar livre e independente de crenças e de qualquer tutela religiosa.

No horizonte da teoria corbiniana, IDS/ICS como cultivo da qualidade humana e da qualidade humana profunda não requer deuses, nem crenças, nem símbolos, nem mitos. Se existem, o importante é que estejam livres da condição predatória e egocentrada. Acima de tudo, como aqui tem-se afirmado, devem estar livres da estrutura de submissão. A esse propósito, não encontramos evidências de que esteja em curso o cultivo de IDS/ICS entre pessoas sem religião. No entanto, estamos convencidos de que se thes poderia apresentar essa alternativa para o cultivo da qualidade humana e da qualidade humana profunda em perspectiva laica ou não religiosa.

O que nos leva a sustentar essa proposição, dado que pessoas sem religião não desejam ter orientada a sua experiência através de instituições, doutrinas ou sistemas de atos? Na perspectiva de uma epistemologia não mítica, segundo a teoria da epistemologia axiológica, o fundamento do que costumamos chamar espiritualidade fica explicitado a partir da compreensão do animal humano como animal de fala.

Diferentemente dos demais animais, os quais interagem com o meio mediante uma estrutura binária de estímulo e resposta, o animal humano interage com o meio por uma estrutura ternária. A interação do ser humano com o meio se desenvolve não só através de estímulos e respostas, mas também pela mediação da fala. Por intermédio da língua, a relação do ser humano com o meio se diferencia e se distancia radicalmente da relação das restantes espécies animais com o meio. Para Corbí, o ser humano, por ser um animal falante, tem acesso a uma dupla dimensão da realidade, a dimensão relativa (DR) e a dimensão absoluta (DA). A primeira dessas experiências se refere à dimensão funcional da vida, a qual se restringe à satisfação das necessidades humanas elementares e ordinárias. 
Essa experiência situa todo indivíduo na dimensão relativa da realidade. A segunda experiência remete à dimensão absoluta da realidade, a qual transcende todas as concepções e medidas humanas acerca do que existe.

Na compreensão de Marià Corbí, os animais humanos por terem assegurados pela linguagem a um duplo acesso ao real, experienciam um acesso a partir das suas necessidades e um outro independente dessas mesmas necessidades. Do primeiro acesso, estabelecem uma relação com a dimensão relativa do real; do segundo, desenvolvem uma relação com a dimensão absoluta do real. Na perspectiva da dimensão relativa, a realidade é percebida como algo constituído por indivíduos portadores de necessidades em meio a uma vasta gama de objetos. Nesse cenário, a realidade não é mais do que uma imensidão de indivíduos e de objetos não só diferenciados como, também, contrapostos uns em relação aos outros. Desse modo, a realidade é sempre compreendida sob o viés da dualidade, como algo fragmentado por elementos não só antagônicos, bem como dissonantes e irreconciliáveis. No entanto, o real não é dual e sequer contém alguma dualidade. ${ }^{52}$

Para o epistemólogo, a experiência absoluta da realidade

[...] não é uma experiência transcendental, como o seria a experiência de uma realidade que ultrapassasse este mundo. Trata-se da experiência deste mesmo mundo, ao qual temos acesso com nossos sentidos, com nossa mente e nossa ação, mas que é visto, compreendido e sentido como existindo e valendo com total independência com relação a nós e a qualquer relação com nós mesmos. ${ }^{53}$

O ser humano, portanto, é apto a um duplo acesso à realidade. Pela sua condição de seres falantes, são habilitados a distinguir uma dimensão da realidade relativa às suas necessidades e a uma dimensão da realidade ab-soluta (separada), ou seja, uma dimensão que existe em si mesma e que independe de nós. A dimensão absoluta não diz respeito a outra coisa que existe além do que existe. Trata-se de uma dimensão inerente ao que existe e que todo animal humano é capaz de experienciar.

$\mathrm{Na}$ atualidade, sob o impacto das mudanças que ocorrem nas sociedades de conhecimento e de inovação, a dimensão absoluta da realidade, do ponto de vista de Corbí, será cultivada inevitavelmente fora da epistemologia mítica, ou seja, fora das fronteiras das religiões. No horizonte de uma epistemologia não mítica ${ }^{54}$ nenhum desses modelos é reconhecido como capaz de descrever a realidade tal como ela é.

\footnotetext{
${ }^{52}$ Cf. CORBÍ, Marià. Una espiritualidad no religiosa desde de la tradición cristiana. Horizonte: Belo Horizonte, v. 12, n. 35, p. 688-715, jul./set. 2014.

${ }^{53}$ CORBÍ, Marià. Para uma espiritualidade leiga. Sem crenças, sem religiões, sem deuses. São Paulo: Paulus, 2010. p. 26.

${ }^{54}$ CORBÍ, Marià. Consecuencias del final de la epistemología mítica. Barcelona: CETR Editorial, $2010 \mathrm{~b}$
} 
Para Marià Corbí, o que se acostumou chamar espiritualidade, e que para o autor é identificado como cultivo da qualidade humana profunda, diz respeito à experiência de conhecer e de sentir a realidade sem a influência da condição necessitada, a qual está limitada à dimensão relativa do real. Espiritualidade é o caminho pelo qual a pessoa vislumbra a dimensão absoluta da realidade pela via da unidade, e não da dualidade. Para adentrar nesse caminho, cada indivíduo terá a difícil tarefa de silenciar a sua condição necessitada e de cultivar uma atitude nova diante de tudo e de todos. Segundo o autor, essa nova atitude é cultivada por meio do conhecimento silencioso ou cultivo da investigação livre.

O conhecimento silencioso, enquanto cultivo da investigação livre, consiste no silenciamento das representações e interpretações que temos a respeito da realidade e que construímos desde a nossa condição necessitada. $\mathrm{Na}$ visão de Corbí, o cultivo da investigação livre ou conhecimento silencioso não é uma interpretação e sequer uma representação da realidade, e nem uma resposta metafísica às questões existenciais do ser humano, mas é um conhecimento experiencial livre de pensamentos e de palavras, ou seja, um conhecimento isento da influência da razão. Silenciar as criações e os desejos advindos da condição necessitada é eliminar qualquer mediação e colocarmo-nos em contato com a dimensão absoluta que é totalmente independente, autônoma e alheia aos nossos pensamentos, projetos e interesses.

É pelo silenciamento da condição necessitada que o animal humano experiencia o mistério da dimensão absoluta, ou o real tal como é. Para o autor, adentramos a dimensão absoluta

[...] quando silenciamos por completo todas as nossas formas de objetivar, de representar, de imaginar, de ter expectativas, de desejar. Quando esse silêncio interior se produz, em estado de alerta, pode ocorrer a revelação dessa outra dimensão do real que transcende todas as nossas concepções e medidas do que é..$^{55}$

É evidente que somos incessantemente seres de necessidades e, devido a esse condicionamento inevitável, vemos e pensamos as coisas e o outro sempre sob a lógica da dualidade. O desafio que Marià Corbí propõe consiste em perceber que a vida não se reduz à sua dimensão relativa, ou evitar identificar a dimensão absoluta com a dimensão relativa da vida. A dimensão relativa exibe um ego ávido de necessidades e desejos. No entanto, a dimensão absoluta do real, o que é, se manifesta como uma realidade não-dual. O "Absoluto se acha vazio de toda possível categorização."

${ }^{55}$ CORBÍ, Marià. Para uma espiritualidade leiga. Sem crenças, sem religiões, sem deuses. São Paulo: Paulus, 2010. p. 209.

${ }^{56}$ CORBÍ, Marià. Para uma espiritualidade leiga. Sem crenças, sem religiões, sem deuses. São Paulo: Paulus, 2010. p. 196. 
Do silenciamento da condição necessitada irrompe o cultivo da qualidade humana profunda que se aparta radicalmente das religiões, as quais se sustentam com crenças que delimitam o que é inominável e inefável. O autor propõe que a dimensão absoluta seja concebida como "livre de toda forma" [embora devamos saber que] ela pode se apresentar em toda forma." ${ }^{57}$

O foco de Marià Corbí está em pensar o desafio do cultivo da qualidade humana e da qualidade humana profunda nos contextos das sociedades de conhecimento e de inovação. Ao constatar que atravessamos uma crise axiológica profunda, quer a nível individual, quer a nível social, e que a cultura contemporânea é afetada por mudanças contínuas e destituída de qualquer fixação, o autor defende a ideia de que tal cultivo da qualidade humana e da qualidade humana profunda terá de ser sem crenças, sem religiões e sem deuses, mediante, portanto, uma epistemologia não mítica. $\mathrm{O}$ autor tenciona apresentar o perfil de uma espiritualidade que ajude de modo efetivo os indivíduos e grupos sociais da atualidade a fazer a experiência da dimensão absoluta da realidade de acordo com a cultura própria do tempo.

Temos evidenciado que, na perspectiva de Corbí, ${ }^{58}$ a expressão que caracteriza o que outrora se denominava espiritualidade, considerado horizonte da epistemologia não mítica, é cultivo da qualidade humana profunda. Tal postura se assenta no fato de o autor considerar ambíguo o termo espiritualidade. Corbí associa esse termo à antropologia dicotômica que separa corpo e espírito. Na visão do autor, qualidade expressa bem aquilo que os nossos antepassados se referiam quando usavam o termo espiritualidade. $\mathrm{O}$ autor pensa o conceito de qualidade sob dois ângulos inseparáveis, embora tenuemente distintos, a saber, o da qualidade humana e o da qualidade humana profunda. A qualidade humana remete ao aprimoramento das faculdades mentais, sensitivas, perceptivas e ativas dos indivíduos ou grupos sociais a fim de conduzir as diferentes áreas da vida humana de forma adequada e sábia. Numa vida imbuída de qualidade humana, os indivíduos têm consciência da dupla dimensão da realidade, conforme acima descrito, ou seja, a dimensão relativa e a dimensão absoluta.

A qualidade humana profunda é como a continuidade de uma vida com qualidade humana, porém segundo uma vivência mais intensa. A diferença é que uma vida pautada pela qualidade humana se submete ainda aos condicionamentos do ego, enquanto que quando regulada pela qualidade

\footnotetext{
${ }^{57}$ CORBÍ, Marià. Para uma espiritualidade leiga. Sem crenças, sem religiões, sem deuses. São Paulo: Paulus, 2010. p. 173.

${ }^{58}$ CORBÍ, Marià. La cualidad humana y la cualidad humana profunda en las sociedades afectadas por la dinámica acelerada de las tecnociencias. Interações, v. 12, n. 21, p. 29-44, 2 ago. 2017b.
} 
humana profunda não há mais submissão. Sob o ângulo da qualidade humana profunda, a vida é pensada e experienciada de forma incondicional e sem influência do ego. A vida é concebida e vivenciada sob inspiração da dimensão absoluta da realidade.

\section{Considerações finais}

O fenômeno da emergência do que aqui nomeamos espiritualidade sem religião está delimitado à análise de pessoas sem religião. Não há nenhuma pretensão de universalidade ou de reducionismo. Procuramos demonstrar que os sem-religião vivenciam uma espiritualidade desvinculada das instituições (desinstitucionalização da crença), de forma autônoma e independente. Também evidenciamos, a partir do campo estudado, que o modo de viver a experiência do que consideram fé está fortemente marcado pela orientação individual (individualização da crença). O presente recorte de um estudo mais amplo ${ }^{59}$ se orientou pela perspectiva das Ciências da Religião. Procuramos apresentar e analisar em perspectiva não normativa, descritiva e sistemática alguns dos dados da pesquisa sobre espiritualidade não religiosa de pessoas sem religião. No presente trabalho, o processo de teorização e de sistematização do fenômeno, evidenciou a possível contribuição da teoria corbiniana da epistemologia axiológica.

O fenômeno se expande ao mesmo tempo em que se consolidam as características das contemporâneas sociedades do conhecimento, as quais se caracterizam por serem dinâmicas, de inovação, sociedades tecnológicas. Esse novo ambiente cultural e civilizatório tem sido responsável por profundas

\footnotetext{
${ }^{59}$ Destacamos aqui alguns dos trabalhos em curso. Cf. VIEIRA, José Álvaro Campos Vieira. Ensaio de espiritualidade não religiosa: estudo a partir de indivíduos sem religião em Belo Horizonte. 327f. Tese (Doutorado) - Pontifícia Universidade Católica de Minas Gerais, Programa de Pós-Graduação em Ciências da Religião, Belo Horizonte, 2020. VIEIRA, José Álvaro Campos. Os sem-religião. Aurora de uma espiritualidade não religiosa. Belo Horizonte: Editora PUC Minas, 2018.Cf. SENRA, Flávio. Acercamiento a la pregunta: ¿Qué es religión? In CORBÍ, Marià (org.). Diferencias y contraposiciones entre una espiritualidad de sumisión y una espiritualidad de indagación y creación libre. Madrid: Ed. Bubok, 2020a. p. 105-118. SENRA, Flávio. Crise e emancipação no horizonte das espiritualidades não religiosas. Horizonte - Revista de Estudos de Teologia e Ciências da Religião, v. 12, n. 35, p. 654-657, 3 out. 2014. SENRA, Flávio. Espiritualidade e contemporaneidade. In: SENRA, Flávio; CAMPOS, Fabiano; ALMEIDA, Tatiane. Religião \& contemporaneidade. Atualidade do fenômeno religioso. São Paulo: Fonte Editorial; Belo Horizonte: 2017, p. 119-129. SENRA, Flávio. Espiritualidade não religiosa. In. RIBEIRO, Claudio de Oliveira; ARAGÃO, Gilbraz; PANASIEWICZ, Roberlei. Dicionário do Pluralismo Religioso. São Paulo: Ed. Recriar, 2020b. SENRA, Flávio; CAMPOS, Fabiano Victor de Oliveira. Senso religioso contemporâneo e os sem-religião: uma provocação a partir de Emmanuel Lévinas. Caminhos, Goiânia, v. 12, n. 2, p. 312-331, jul./dez. 2014. SENRA, Flávio; CARVALHO, Izabella Faria de; VIEIRA, José Álvaro Campos. Os sem-religião: Espacialização e vozes de uma transformação. Caderno de Geografia. v. 30, n. 61, p. 480-498, abr./jun. 2020.
} 
transformações no nosso tempo. As mais variadas áreas da vida humana são afetadas por transformações que têm impacto na forma de pensar e de agir com relação ao mundo que recebemos de nossos antepassados.

Para compreender a ruptura que pessoas sem religião demonstram ter com relação às instituições religiosas, seu corpo doutrinário e seu sistema de atos, apoiamo-nos na teoria de Corbí. Segundo o autor, a religião, considerada um PAC com características das sociedades pré-industriais e estáticas, está marcada por valores como submissão e disciplina. As narrativas que deram origem à religião explicitam a força do poder coercivo e baseiam-se na noção de submissão a uma ordem. Marcados por uma cultura de individualização, as pessoas sem religião professam que não aceitam esse tipo de controle e condução para o que consideram ter fé.

Por um lado, temos que a consolidação das sociedades pré-industriais foi levada a cabo através do princípio da coerção social explícita. Este princípio foi exercido por uma forte liderança e gozou de todo um aparelho para assegurar a sobrevivência do grupo. A rotina e a hierarquia foram bem demarcadas, e a liderança religiosa atuou para assegurar a obediência e o controle através de narrativas e rituais. A liberdade acabou por ser um ataque ao poder e ao sistema de controle das sociedades pré-industriais.

Por outro lado, os sujeitos sem religião que pesquisamos, evidenciam o maior apreço pelo princípio da liberdade. Tal é o princípio que, forjado nas modernas sociedades industriais, se torna um imperativo nas atuais sociedades do conhecimento e da inovação. $O$ modelo baseado na coerção explícita, rotina e hierarquia não é valorizado neste novo contexto. Uma estrutura religiosa baseada no princípio da submissão se choca com o princípio da liberdade que caracteriza as sociedades do conhecimento e que fundamenta, tanto os processos de individualização das crenças quanto os processos de desinstitucionalização religiosa.

Percebemos que a religião, considerada como institucionalização do modelo de submissão pré-industrial, vem sendo abandonada por esses sujeitos sem religião. Tais pessoas não reconhecem o gerenciamento da dimensão de suas crenças feito por autoridades e instituições religiosas. Quando observamos o discurso de pessoas que se afirmam sem religião, encontramos elementos que nos permitem reconhecer o despertar de uma espiritualidade que não admite o princípio da submissão baseada na coerção.

O processo de desinstitucionalização identificado entre pessoas sem religião nos parece representar um grave desafio. $\mathrm{O}$ cultivo da dimensão absoluta da realidade, condição própria de animais de fala, estará ameaçado? Não foi possível ainda chegarmos a compreender se tal cultivo vem sendo observado por tais pessoas. Em princípio, o que parece existir é uma herança dos modos de crer em perspectiva mítica. 
Embora a epistemologia mítica se apresente inadequada nas modernas sociedades de conhecimento e de inovação, Marià Corbí afirma que não podemos colocá-las de lado ou simplesmente arquivar as tradições religiosas. Há que se preservar aquilo que é valioso no legado das grandes tradições de sabedoria e dos mestres espirituais. Contudo, lembra Corbí, tais narrativas não dizem sobre em que se deve crer, mas estimulam a buscar uma dimensão da realidade além das fronteiras das necessidades e dos condicionamentos. Desse modo, todo indivíduo que deseja cultivar a qualidade humana é instigado a reavivar o legado das tradições religiosas e dos mestres espirituais sem, contudo, ser ou tornar-se religioso no sentido de submeter-se a algum tipo de crença.

Mudam as culturas e os enredos históricos, mudam as pessoas e as sociedades, e mudam também as formas de acesso à dimensão absoluta da realidade. No entanto, a dimensão absoluta subiste. A dimensão absoluta independe e é autônoma de nós e da superficialidade de todas essas mudanças e condicionamentos. Não existe uma forma de experienciar, pois a "a espiritualidade é liberdade de toda forma e de toda fôrma." ${ }^{60} \mathrm{O}$ valor do legado dos antigos não está na experiência, mas naquilo que eles sinalizam - a existência de uma dimensão absoluta da realidade.

Segundo Marià Corbí, o cultivo da qualidade humana profunda, é um caminho sem itinerário predefinido, sem mapa nem guia. $\mathrm{O}$ autor apenas nos indica por onde iniciar, ou seja, pelo cultivo do silenciamento de nossa condição necessitada, isto é, pela supressão de todas as interpretações, representações e desejos que acumulamos desde a dimensão relativa da realidade. Por meio desse silenciamento, opera-se a passagem de uma noção dual para uma percepção não dual da vida. $\mathrm{O}$ indivíduo que experiencia esse silenciamento se depara com o real tal como é, e não consoante com o que pensa ou necessita. O conhecimento silencioso não é um saber oculto ou esotérico sobre a realidade, mas um saber que faz presenciar o real desprovido das construções da condição necessitada. Silenciar a condição necessitada não é sinônimo de apatia para com a realidade. Pelo contrário, é ousar calar o ego para poder conhecer e sentir outra dimensão do mesmo real.

O conhecimento silencioso enquanto cultivo da investigação livre possibilita aos homens e mulheres das sociedades atuais uma atitude de respeito e acolhimento a tudo o que existe. Trata-se de uma experiência que estimula os indivíduos a ter uma postura diferenciada e propositiva diante dos desafios da vida cotidiana. Na perspectiva de Marià Corbí, sem o silenciamento da condição necessitada não haverá ciência, arte ou outra atividade que promova uma vida de qualidade para a humanidade. $\mathrm{Na}$

${ }^{60}$ CORBÍ, Marià. Para uma espiritualidade leiga. Sem crenças, sem religiões, sem deuses. São Paulo: Paulus, 2010. p. 169. 
ausência da relação com a dimensão absoluta, a vida individual e social será conduzida continuamente pelo viés da competição e depredação, e jamais haverá respeito a qualquer outro, construção de projetos promissores à vida dos indivíduos e da coletividade, e preservação.

O diagnóstico de Corbí a respeito das sociedades do conhecimento, sociedades baseadas na mudança contínua, criatividade e liberdade, evidencia as dificuldades para as formas religiosas baseadas na submissão, chave para compreendermos o fenômeno da espiritualidade não religiosa de pessoas sem religião nesse trabalho. Corbí propõe o cultivo do conhecimento silencioso ou cultivo da investigação livre. O caminho para este cultivo, segundo o pensador, faz com que a modelagem centrada na necessidade permaneça silenciosa. O futuro dessa investigação consiste em procurarmos pelo modo como pessoas sem religião cultivam IDS-ICS, ou seja, sobre como cultivam interesse, desprendimento e silenciamento (IDS), e, indagação, comunicação e serviço (ICS).

\section{Referências}

AMARAL, Leila. Cultura religiosa errante. O que o Censo de 2010 pode nos dizer além dos dados. In: TEIXEIRA, Faustino; MENEZES, Renata (orgs.). Religiões em movimento. O Censo de 2010. Petrópolis: Vozes, 2013, p. 295-310.

AUGUST, Hartmut.; ESPERANDIO, Mary Rute Gomes. Apego a Deus: revisão integrativa de literatura empírica. Horizonte - Revista de Estudos de Teologia e Ciências da Religião, v. 17, n. 53, p. 1039, 31 ago. 2019.

BARROSO, Victor Breno Farias. Modernidade religiosa: memória, transmissão e emoção no pensamento de Danièle Hervieu-Léger. São Paulo: Fonte Editorial, 2014.

BAUMAN, Zygmunt. A cultura no mundo líquido moderno. Rio de Janeiro: Zahar, 2013. BOFF, Leonardo. Crise. Oportunidade de crescimento. Campinas: Verus, 2002.

CORBÍ, Marià. El destino de las nuevas sociedades industriales está solo en nuestras manos. Horizonte: Belo Horizonte, v. 9, n. 23, p. 821-838, out./dez. 2011.

COMTE-SPONVILLE, André; FERRY, Luc. A sabedoria dos modernos. Dez questões para o nosso tempo. Lisboa: Instituto Piaget, 2016.

CORBÍ, Marià. Para uma espiritualidade leiga. Sem crenças, sem religiões, sem deuses. São Paulo: Paulus, 2010.

CORBÍ, Marià. Análisis epistemológico de las configuraciones axiológicas humanas. La necesaria relatividad cultural de los sistemas de valores humanos: mitologías, ideologías, ontologías y formaciones religiosas. Salamanca: Ediciones Universidad de Salamanca, 1983.

CORBÍ, Marià. Consecuencias del final de la epistemología mítica. Barcelona: CETR Editorial, 2010b. 
CORBÍ, Marià. El gran olvido: la gratuidad del vivir. Principio de Epistemología Axiológica 6. Madrid: Ed. Bubok, 2020a.

CORBÍ, Marià. La cualidad humana y la cualidad humana profunda en las sociedades afectadas por la dinámica acelerada de las tecnociencias. Interações, v. 12, n. 21, p. 29-44, 2 ago. $2017 \mathrm{~b}$.

CORBÍ, Marià. La sabiduría de nuestros antepasados para sociedades en tránsito. Principios de Epistemología Axiológica 2. Madrid: Ed. Bubok, 2013.

CORBÍ, Marià. Las sociedades de conocimiento y la calidad de vida. Principios de Epistemología Axiológica 5. Madrid: Ed. Bubok, 2017.

CORBÍ, Marià. Proyectar la sociedad, reconvertir la religión. Los nuevos ciudadanos. Barcelona: Herder, 1992.

CORBÍ, Marià. Proyectos colectivos para sociedades dinámicas. Principios de Epistemología Axiológica. Barcelona: Herder, 2020b.

CORBÍ, Marià. Reflexiones sobre la cualidad humana en una época de cambios. Barcelona: Verloc/CETR, 2012.

CORBÍ, Marià. Religión sin religión. Madrid: PPC, 1996.

CORBÍ, Marià. Una espiritualidad no religiosa desde de la tradición cristiana. Horizonte: Belo Horizonte, v. 12, n. 35, p. 688-715, jul./set. 2014.

DURKHEIM, Émile. As formas elementares de vida religiosa: o sistema totêmico na Austrália. 2. ed. São Paulo: Paulus, 1989.

ESPERANDIO, Mary Rute Gomes et al. Coping Religioso/Espiritual na Antessala de UTI: Reflexões sobre a Integração da Espiritualidade nos Cuidados em Saúde. Interações, v. 12, n. 22, p. 303-322, 28 dez. 2017.

ESPERANDIO, Mary Rute Gomes et al. Religiosidade/espiritualidade (R/E) em profissionais/trabalhadores da saúde. Interações, v. 10, n. 18, p. 195-209, 31 dez. 2015.

ESPERANDIO, Mary Rute Gomes. Espiritualidade no contexto da saúde: uma questão de saúde pública? In.: LEMOS, Carolina Teles; MARTINS FILHO, José Reinaldo F. Religião, espiritualidade e saúde: os sentidos do viver e do morrer. Belo Horizonte: Editora Senso, 2020.

FILORAMO, Giovanni; PRANDI, Carlo. As Ciências das Religiões. São Paulo: Paulus, 1999.

GAUCHET, Marcel. Le désenchantement du monde: une histoire politique de la religion. Paris: Gallimard, 1985.

GRESCHAT, Hans-Jürgen. O que é Ciência da Religião. São Paulo: Paulinas, 2005.

HARRIS, Sam. Waking up. Searching for spirituality without religion. New York: Simon \& Schuster, 2014.

HALBWACHS, Maurice. A memória coletiva. São Paulo: Centauro, 2003.

HEFTI, René; ESPERANDIO, Mary Rute Gomes. The Interdisciplinary Spiritual Care Model: A holistic Approach to Patient Care. Horizonte - Revista de Estudos de Teologia e Ciências da Religião, v. 14, n. 41, p. 13-47, 31 mar. 2016. 
HERVIEU-LÉGER, Danièle. O peregrino e o convertido. A religião em movimento. Petrópolis: Vozes, 2008.

LIPOVETSKY, Gilles. A era do vazio. Ensaios sobre o individualismo contemporâneo. Barueri: Editora Manole, 2005.

PRAT-I-PUBILL, Queralt. Axiological knowledge in a knowledge driven world. Considerations for organizations. 173f. Tese (Doutorado) - Doctoral School of Organisation and Management Studies, Copenhagen, 2018.

RIVERA, Paulo Barrera. Tradição, transmissão e emoção religiosa. Sociologia do protestantismo contemporâneo na América Latina. São Paulo: Olho d'Água, 2001.

SANCHIS, Pierre. Pluralismo, transformação, emergência do indivíduo e de suas escolhas. Cadernos IHU em formação, a grande transformação no campo religioso brasileiro, São Leopoldo, ano VIII, n. 43, p. 36-39, 2012.

SENRA, Flávio. Acercamiento a la pregunta: ¿Qué es religión? In CORBÍ, Marià (org.). Diferencias y contraposiciones entre una espiritualidad de sumisión y una espiritualidad de indagación y creación libre. Madrid: Ed. Bubok, 2020a. p. 105-118.

SENRA, Flávio. Crise e emancipação no horizonte das espiritualidades não religiosas. Horizonte - Revista de Estudos de Teologia e Ciências da Religião, v. 12, n. 35, p. 654-657, 3 out. 2014.

SENRA, Flávio. Espiritualidade e contemporaneidade. In: SENRA, Flávio; CAMPOS, Fabiano; ALMEIDA, Tatiane. Religião E contemporaneidade. Atualidade do fenômeno religioso. São Paulo: Fonte Editorial; Belo Horizonte: 2017, p. 119-129.

SENRA, Flávio. Espiritualidade não religiosa. In. RIBEIRO, Claudio de Oliveira; ARAGÃO, Gilbraz; PANASIEWICZ, Roberlei. Dicionário do Pluralismo Religioso. São Paulo: Ed. Recriar, 2020b.

SENRA, Flávio; CAMPOS, Fabiano Victor de Oliveira. Senso religioso contemporâneo e os sem-religião: uma provocação a partir de Emmanuel Lévinas. Caminhos, Goiânia, v. 12, n. 2, p. 312-331, jul./dez. 2014.

SENRA, Flávio; CARVALHO, Izabella Faria de; VIEIRA, José Álvaro Campos. Os sem-religião: Espacialização e vozes de uma transformação. Caderno de Geografia. v. 30, n. 61, p. 480-498, abr.jun. 2020.

SOUZA, Jonathan Felix de. Inteligência espiritual: um estudo sobre o despertar de uma espiritualidade não religiosa como qualidade humana profunda nas organizações. 137f. Dissertação (Mestrado) - Pontifícia Universidade Católica de Minas Gerais, Programa de Pós-Graduação em Ciências da Religião, Belo Horizonte, 2020.

STEIL, C. A.; TONIOL, R. A crise do conceito de religião e sua incidência sobre a antropologia. In: GIUMBELLI, E.; BÉLIVEAU; V. G. (orgs.). Religión, cultura y política en las sociedades del siglo XXI. Buenos Aires: Biblos, 2013. p. 137-158.

STEIL, Carlos. A modernidade fragmentou o campo religioso e fez emergir uma diversidade de religiões. Cadernos IHU em formação, a grande transformação no campo religioso brasileiro, São Leopoldo, ano VIII, n. 43, p. 83-86, 2012.

TAYLOR, Charles. A era secular. Lisboa: Instituto Piaget, 2012. 
TEIXEIRA, Faustino. Experiência religiosa: abordagem das Ciências da Religião. Disponível em: http://theologicalatinoamericana.com/?p=203. Acesso em: 29 jul. 2019.

VAZ, Henrique C. de Lima. Escritos de Filosofia. Problemas de fronteira. São Paulo: Loyola, 1986.

VIEIRA, José Álvaro Campos Vieira. Ensaio de espiritualidade não religiosa: estudo a partir de indivíduos sem religião em Belo Horizonte. 327f. Tese (Doutorado) - Pontifícia Universidade Católica de Minas Gerais, Programa de Pós-Graduação em Ciências da Religião, Belo Horizonte, 2020.

VIEIRA, José Álvaro Campos. Os sem-religião. Aurora de uma espiritualidade não religiosa. Belo Horizonte: Editora PUC Minas, 2018.

WEBER, Max. Economia e Sociedade. Fundamentos da sociologia compreensiva. v. 1, 4. ed. São Paulo: Editora UNB, 2004.

Endereço dos Autores:

José Álvaro Campos Vieira

Rua José Napoleão, 355

Apto. 901, Bloco A

Bairro Meireles

60170-210 Fortaleza - CE

alvaroce@msn.com

Flávio Senra

PPGCR PUC Minas

Depto. Ciências da Religião

Av. Dom José Gaspar, 500 - Prédio 4 - Sala 204-B

30535-901 Belo Horizonte - MG

flaviosenra@pucminas.br 